This is the author version of the chapter accepted for publication in D. Garrisi \& J. Johanssen (Eds.). Other Bodies: Disability, Media, and Representations. Milton Park: Routledge.

\title{
The education of children with disabilities in South African online news reports
}

Elizabeth Walton and Judith McKenzie

\begin{abstract}
Many children with disabilities are not attending schools in South Africa. This is despite the country being a signatory to the UN Convention on the Rights of Persons with Disabilities and the promulgation of various local policies to secure the right to inclusive education. Quite often, online news outlets (re)visit this topic in articles. Drawing on analytical tools derived from a broad critical theory, we advance a resistant reading of articles on the education of children with disabilities in South Africa published between 2013 and 2018. Critical disability studies informs the interpretation and explanation of the texts we analyse, as we are interested in how they work to position disability within the wider South African discourses about education and educational neglect. We argue that the way in which disability is portrayed in these articles presents a simplistic, medicalised approach and one of individual tragedy. This portrayal evokes shock and pity, but ultimately achieves little more than an exercise in public handwringing. We offer a resistant understanding that enables us to think about how this toxic mix of private tragedy and public failure creates an intractable problem with no evident solution. We consider how this might be reconfigured to enable advocacy toward educational access and participation for children with disabilities.
\end{abstract}




\section{Introduction}

As we start to write this chapter, a group of South African people with disabilities and disability rights activists is making a submission to the United Nations (UN) Committee on the Rights of Persons with Disabilities in Geneva. The group is arguing that the South African Department of Basic Education (DBE) is not doing enough to secure the realisation of the right to an inclusive education, as envisaged by the UN Convention on the Rights of People with Disabilities. South Africa signed this Convention and the Optional Protocol in 2007 and in so doing committed the country to recognising the rights of persons with disabilities to education and ensuring, “... an inclusive education system at all levels” (UN 2006, 24 (1)). The group submission to the UN committee echoes the findings of a Human Rights Watch report that was published in 2015. Titled "Complicit in exclusion", the report presented evidence of 500000 children with disabilities not in school in South Africa. These children experience discrimination in attempts to enrol in schools and in accessing 'reasonable accommodations' within schools (Human Rights Watch 2015). This is despite South Africa's commitment to an inclusive education system, envisaged in the 2001 White Paper Six on Special Needs Education (Department of Education (DoE) 2001). The press has been quick to report on the failure of the government to provide education for children with disabilities, and our concern in this chapter is to explore how online newspaper articles portray this issue. Drawing on analytical tools derived from a broad critical theory, we advance a resistant reading of articles published between 2013 and 2018. We argue that these articles rehearse negative stereotypes about children and young people with disabilities, coopting them into the journalistic expose of individual tragedy neglected within an uncaring system, but without framing the issues in wider systemic failure and the socio-historical context of apartheid. This sets up a vicious cycle where children who have impairments are disabled by an environment of systemic neglect. To provide some context of the conditions 
that have created such a mix, we first discuss the history of educational provision for children with disabilities in South Africa.

\section{Education of children with disabilities in South Africa}

The Apartheid government which came to power in South Africa in 1948 inherited legislation which related to "The education of the handicapped child" (Republic of South Africa (RSA) 1948, section 1). This legislation laid the groundwork for a medicalised approach to separate special education for children with disabilities. Section One of The Act of 1948 defined the "handicapped child" as one who deviates from the majority, making disability a deviant characteristic. The focus was on what the child cannot do (i.e. benefit from "normal" instruction) and should not do (attend "ordinary" classes because it would be harmful to "him" or others). In the light of this, the 1948 Act made provision for "special schools and homes for the classes of handicapped children" (RSA 1948, Section 2(1)), with the assumption that different types of 'handicap' demanded different schools. The government built on this 1948 Act with subsequent policies that secured special education for white children under the auspices of a separate special education department in conjunction with the four provincial education departments. Special education for children of other races was handled by the education departments set up for each race group and was not administered apart from regular education. Very few special schools were built by these departments, and most special schools that existed for black children with disabilities were established and maintained by charitable or missionary organisations. Specialising in teaching children with disabilities was not offered in the black universities (Skuy and Partington 1990) and remedial teaching only began to be offered to a limited extent in black schools in the early 1990s (Nkabinde, 1993). 
The result of these apartheid era policies was the democratically elected government of 1994 inherited an education system that was highly fragmented, and which carried the legacy of inequitable and racist policies. The results of these policies included a large percentage of children with disabilities out of school (in 2001 only $20 \%$ of all children with disabilities were in special schools (DoE 2001, 38)); inadequate specialist school and staff provision for the whole population; existing special schools clustered in former whites-only areas; and negative attitudes towards people with disabilities. To address these issues, the unified, nonracial Department of Education set up a commission to investigate and make recommendations about special needs and support in education. A major move in understanding support was the adoption of the concept of 'barriers to learning' which framed disability as one of the many barriers that children face in accessing quality education. While disability was represented as an element of diversity, the distinction between intrinsic barriers to learning (organic and within the child) and extrinsic such as poverty or an inflexible curriculum was maintained. The commission's report recommended the integration of the special and ordinary education system in a seamless educational support system, and in 2001, White Paper Six: Special Needs Education: Building an Inclusive Education and Training System was published.

White Paper Six (DoE 2001) sets out a framework for South Africa's education system to become inclusive. Built on constitutional values like the right to education and freedom from discrimination, the White Paper envisages an education system where difference is valued, participation is maximised, and diverse learning needs are met through changed attitudes, behaviours and teaching methodologies. The binary distinction between psychosocial barriers on the one hand and organic barriers on the other was retained in considering these learning needs. Various strategies were to be implemented to achieve this vision of inclusive 
education, including improving special schools; converting some schools to become 'fullservice schools' with the capacity to include children with moderate support needs; teacher education; and the development of support structures at various levels in the system. The strategy is predicated upon the two pillars of a) screening, identification, assessment and support (DBE 2014) and b) curriculum differentiation to enable an effective response to diverse learning needs (DBE 2011). The research literature shows that the years since 2001 have seen some progress towards more inclusive schooling (Walton 2011) but also significant evidence of the non-implementation of the policy. Reasons for this are given as inadequate expenditure and poor resourcing; negative attitudes towards difference; teachers' sense of un(der)preparedness for inclusive classrooms; and an inflexible curriculum (Donohue and Bornman 2014). The implementation of policy has also demonstrated a complex practice around disability where it has become less visible as a distinct entity but rather as but one form of diversity to be dealt with through inclusive classroom practice. However, disability also becomes highly visible through elaborate assessment and placement practices that ultimately serve to place children with disabilities in segregated settings on the pretext of having high levels of support (McKenzie, Kelly and Shanda 2018). Despite these legislative and policy initiatives, the exclusion of children with disabilities from schooling has continued (Fleisch, Shindler and Perry 2012), and has become an issue of public interest, as evidenced by various newspaper articles. This is not unique to South Africa, and news articles on matters to do with disability have captured the attention of scholars.

\section{Disability in the news}

Media both reflects and reproduces extant societal attitudes towards, and ideas about disability (Phillips 2012). Media shapes attitudes through topic selection, i.e., what the article is about, where the article is found, i.e., news articles or features like letters and reviews, and 
what terminology is used (Wilkinson and McGill 2009). It has been shown that media representations of people with disabilities are problematic (Zhang and Haller 2013), either because people with disabilities are invisibilised, or because the media perpetuates stereotypes. Barnes (1992) notes common media stereotypes of disabled people as pitiable and pathetic, as a burden, as incapable of participating in community life and as victims of violence, amongst others. These stereotypes have been linked to a medicalised view of disability, where the focus is on people's need for medical support; to a social pathology model, which portrays people with disabilities as socially disadvantaged and in need of social support; and to a 'supercrip' model, which describes people with disabilities as superhuman, overcoming impossible odds (Clogston 1990 in Zhang \& Haller 2013). Wood (2012) further notes that the media tends to focus on either the over or under achievement of people with disabilities, thereby obscuring their actual experience. This serves to distance people with disabilities from the consumers of media who come to perceive disability as a challenge to be overcome or succumbed to, rather than a complex social process. In South Africa, the 'Ag shame' category of stereotype has been identified (McDougall 2006). Named after a local idiom that signifies tragedy and pity, this stereotype captures "that disability is always pathetic, that disability is dependent. It's presented as disabled people are very innocent, and very much deserving of one's sympathy” (McDougall 2006, 388). The 'ag shame' stereotype has elements of the social pathology model, in that people with disabilities are cast as needing support because of their own helplessness.

\section{A critical approach}

Our approach to the news articles is informed by analytical traditions that emanate from critical theory, which "insists on revealing power dynamics" (Meekosha and Shuttleworth 2009, 59). These analytical traditions are critical disability studies and critical literacy. They 
have in common a "critical distancing from, and then oppositional reengagement with, the dominant culture” (Brookfield 2005, 13). Critical disability studies, says Goodley (2013, 2017), engages with the corporeality of disability and with inter/transectionality, acknowledging the matrices of power that dis/privilege various identity markers. It challenges ableism and the hegemony of normative notions of what it means to be human and resists the pathologisation of difference. Critical disability studies opposes binary thinking and is concerned with the complex "relational, cultural and psychological implications of disability" (Flynn 2017, 155). In this sense it represents an evolution and increasing complexity of the original formulation of the social model with its sharp divide between impairment and disability and its strong historical materialist foundation (Meekosha and Shuttleworth, 2009).

The emphasis on cultural, psychological and discursive elements of critical disability studies is not without its critics especially in its application in the Global South. Grech $(2017,18)$, for example, expresses the view that:

Abstract projects [critical disability studies] .... may constitute a gross offence to disabled people preoccupied with very material poverty and oppression, for whom decolonisation is about freedom of their land, labour, religion, knowledge and bodies, all of which are historically referential.

We are acutely aware of this tension in our discursive analysis and keep the material consequences of years of apartheid and continuing poverty in our sights when engaging with the news articles.

Critical literacy refers to the "use of the technologies of print and other media of communication to analyze, critique, and transform the norms, rule systems, and practices governing the social fields of everyday life" (Luke 2012, 5). The central tenets of critical 
literacy have been taken up in analyses of verbal text, visual images and multimodal texts. These approaches all work with the assumption that "... all texts are positioned and positioning" (Janks 2010, 61), and that this positioning has an effect on readers. Exposing these effects is the task of the critical reader. There is no "universal model" (Luke 2012,9) of critical literacy, or of the critical analysis of texts, but many approaches reflect in some way Fairclough's (2001) Critical Discourse Analysis. This embeds texts within processes and possibilities of production and interpretation, which in turn are embedded in wider sociocultural practices (Fairclough 2001; Janks 2005). These three layers offer 'stages' of analysis, first in terms of the description of the text in which its properties (linguistic and visual features) are considered. The second stage is interpretation which refers to the interaction process between the participants (text producer and text analyst) and the text. Third is the explanation stage. The objective of this stage is,

... to portray a discourse as part of a social process, as a social practice, showing how it is determined by social structures, and what reproductive effects discourses can cumulatively have on those structures, sustaining them or changing them (Fairclough 2001, 135).

Critical disability studies informs the interpretation and explanation of the texts we analyse, as we are particularly interested in how they work to position disability within the wider South African discourses about education and educational neglect. We are concerned to expose the ways in which particular, taken-for-granted ways of viewing the world are legitimated and habituated through the news articles. Some of these taken-for-granted views include disability being regarded as "something static, something beheld from afar, not complex, not shifting in meaning" (Biklen 2000, 339). Related to this unwillingness to 
engage with the complexity of disability is a simplistic notion that there are "two educational systems - one for disabled students and one for everyone else" (Erevelles 2000, 25).

In this chapter, we offer a resistant reading of selected news articles. The idea of resistant reading is aligned to Luke and Freebody's $(1990,13)$ fourth role of the reader, the "text analyst". The other roles are as "code breaker" (8), "text participant" (9) and "text user" (10). The text analyst is aware of how language and ideology work in the design of the text to position both the topic and the reader, and understands how this contributes to certain perspectives being built and reinforced. Resistant reading of media also echoes Stuart Hall's notion of 'resistant spectatorship' (1973, in Tewell 2016). Resistant spectatorship understands but opposes the intended messages of texts and challenges the dominant beliefs that the texts encode. The reader or viewer is strongly agentic in this engagement with the text, and "reads a text against itself” (Tewell 2016, 291). Janks $(2010,22)$ explains resistant reading as The interrogation of texts ... [that] implies that readers recognise texts as selective versions of the world; they are not subjected to them and they can imagine how texts can be transformed to represent a different set of interests.

\section{Methodology}

Our initial awareness of online news articles addressing the issue of the education of children with disabilities in South Africa came from our work in the field. Our concern about the ways in which the education of children with disabilities was presented led to this more systematic study. Based on the content of the articles we initially encountered, we conducted a Google search with the search terms 'news', 'disability', 'special education needs' 'education' and 'South Africa'. We chose to limit the date of publication to the five years prior to 31 January 2018 to ensure that the analysis could be regarded as reasonably current and represents a time 
period in which inclusive education policy was well into the implementation stage. This search yielded twenty-eight articles from online news sites. Due to the retrospective nature of the analysis, we limited the work to online news articles, acknowledging that there may be other articles in the print news which we could not easily access. We then further restricted the search to free-to-read articles that were published in English. We excluded items that were primarily multi-media, i.e., video rather than text report, so the analysis was not done across genres. On close reading of the content, further articles were excluded, based on whether they were, in fact, about schooling for children with disabilities. This process yielded fifteen articles, which are presented in Table 1 together with available information on the publication. All links were accessed and confirmed live on 5 February 2018, and a printable version was downloaded for each article. This was done in acknowledgement of the instability of online content, and knowing that some platforms remove articles and archive them. The fifteen articles formed the data set for this study, and the set was deemed broad enough to provide a range of media outlets across the years, while also allowing for an indepth analysis of each article. 


\section{News platform}

Mail \& Guardian Online

Describes itself as "A pan-African daily online newspaper, published all day, all week, aimed at serious and not-so-serious readers"

The newspaper describes its readers as "Broad-based readership of South Africans and Africans who prefer their daily news to be indepth and insightful. Plus a large readership abroad of expats, would-be tourists, foreigners with a special interest in Africa and more. A generally argumentative bunch"

Source: https://mg.co.za/page/about-us

HeraldLIVE is the online presence of The Herald, self described as "the voice of Nelson Mandela Bay" in the Eastern Cape of South Africa. HeraldLIVE publishes "fresh news, insights, opinions, sport and entertainment reports all day long, seven days a week on a fully mobile responsive website"

Source: https://www.heraldlive.co.za/about-us/ SowetanLIVE says that it is, "SowetanLIVE, the website of the Sowetan, the English-language South African daily newspaper that started in 1981 as a liberation struggle publication ... The website carries content from the print edition of the Sowetan along with unique online-only content ... general and political news; entertainment and celebrities; soccer and other sport ... It is one of South Africa's largest online news publications, with more than 1.5 -million readers per month"

Source: https://www.sowetanlive.co.za/about-us/
Articles by URL

No place for disabled children in KZN's rural schools. Victoria John

https://mg.co.za/article/2014-10-17-no-place-for-disabled-children-in-kzns-ruralschools

Learners with disabilities need tech. Lloyd Gedye

https://mg.co.za/article/2016-05-27-00-learners-with-disabilities-need-tech

Struggle continues for disabled children. Victoria John

https://mg.co.za/article/2015-02-06-struggle-continues-for-disabled-children

Disabled pupils' hostel of horror. Victoria John

https://mg.co.za/article/2013-08-30-disabled-pupils-hostel-of-horror

Blind schooling in 'shocking' state. Tim Fish Hodgson \& Silomo Khumalo

https://mg.co.za/article/2015-06-11-blind-schooling-in-shocking-state

Schools deaf, blind to pupils' needs. Victoria John

https://mg.co.za/article/2015-11-23-schools-deaf-blind-to-pupils-needs

Thousands of EC special needs pupils 'being set up for failure' Ntombesizwe

Botha.

http://www.heraldlive.co.za/news/2017/03/06/thousands-ec-special-needs-pupilsset-failure/

'I want to read, write', Bongekile Macupe

https://www.sowetanlive.co.za/news/2015-02-21-i-want-to-read-write/ 


\section{IOL}

Independent Media includes 20 of South Africa's "most prominent newspapers". IOL (Independent Online) is "Independent's digital offering, and brings millions of readers breaking news as events happen in the country and around the world. With a growing daily unique online audience, iol.co.za is one of the largest news and information websites in South Africa."

Source: https://www.iol.co.za/about-iol
Special needs education learners achieved 906 bachelor passes. Noni Mokati https://www.iol.co.za/news/south-africa/gauteng/special-needs-educationlearners-achieved-906-bachelor-passes-12612143. 4 January 2018

Calls for more special needs schools in SA. Marvin Charles

https://www.iol.co.za/capeargus/news/calls-for-more-special-needs-schools-insa-10285985. 14 July 2017

9600 special needs children on school waiting lists. ANA reporter

https://www.iol.co.za/news/south-africa/9-600-special-needs-children-on-schoolwaiting-lists-7662646. 8 February 2017

Special needs schoolslack support staff. Ishara Dhanook

https://www.iol.co.za/thepost/special-needs-schoolslack-support-staff-12304086.

3 December 2017

'My disabled child travels 70km to attend school'. Benida Phillips

https://www.iol.co.za/news/south-africa/northern-cape/my-disabled-child-travels70km-to-attend-school-7510132. 26 January 2017

Special schools out of reach of poor. Jabulile S. Ngwenya

https://www.iol.co.za/news/south-africa/western-cape/special-schools-out-ofreach-of-poor-1949731. 23 November 2015

No room in schools for disabled kids. Charlotte Chipangura

https://www.iol.co.za/lifestyle/family/parenting/no-room-in-schools-for-disabledkids-1549502. 19 July 2013

Table 1: Analysed articles from 31 January 2013 to 31 January 2018 
The texts, as online news articles, are multimodal texts, which means that they incorporate "visual images, hypertext, and graphic design elements along with written text" (Serafini 2011, 342). Analysing the texts required that attention was given to the constituent parts of the texts, while also attending to the ways in which these work together. Visuals, for example, can support or subvert the message of the verbal text (Janks 2010). While acknowledging the significance of the visual components of the texts, we have, in the interest of focus and brevity in this chapter, excluded the visual image from our analysis.

The analysis sought to answer the questions of what the articles said about children with disabilities and their education, and how this was conveyed. To establish what the articles said, we conducted a thematic analysis (McMillan and Schumacher 2010) on the articles. This involved a first level of coding of the content of the texts, finding patterns of repetition, and then clustering the codes into categories. Through this process, we identified four major concerns regarding the education of children with disabilities which are repeated across the articles. These are access to schooling, quality of schooling, government responses, and distinctions between the demands of different 'types' of disability. Then, using Fairclough's (2001) notions of description and interpretation, we sought to identify the stylistic and other devices chosen by the article writers to convey their message and what the possible intent and effect of these choices are. We identified linguistic features of the texts and also focused on the headlines. These linguistic features included lexical choices, transitivity, voice, direct and indirect speech, mood, tense, and modality (Janks 2010, 74-75). Within the constraints of this chapter, we present some of the "patterns of use" (Janks 2010, 73) of linguistic features that can be found in a range of the texts. The final aspect of analysis is social analysis or 
explanation (Fairclough 2001). This reflects a resistant reading of these texts, focusing on the socio-cultural and political positioning of the topic, and the reader.

We are more than aware of the limitations of this study. It is small, context-bound and conducted by two people. There may be more articles online than those we used, and we recognise the role of search engine optimisers (SEOs) in determining what is found. We are also acutely aware that a discussion of the important aspects of the "institutional and economic" structures of the newspapers and their "political relations" (Fowler 1991, 90) are beyond the scope of this chapter. Despite this, we suggest that the media serves as an indicator of societies' progress (or lack thereof) in realising the rights of people with disability and that there is continued value in critically engaging with the media's construction of disability. In the section that follows, we outline what the online media reports about schooling for children and young people with disabilities in South Africa.

6. Disability and schooling: What the online news media reports

\subsection{A similar story}

The fifteen newspaper articles analysed rehearse a similar story, with recurring elements. The first issue concerns children with disabilities' formal access to schooling, and special schooling in particular. Here, the following are highlighted:

- There are numbers of children with disabilities not in school (in nine of the articles).

- There are inadequate special schools (in nine of the articles).

- There are various barriers to accessing the schools that exist, including cost for parents, distance to be travelled, inadequate boarding facilities, and schools unable or unwilling to enrol children (in six of the articles). 
The second issue concerns the quality of schooling that children with disabilities experience, either in mainstream or special schools. On this issue, the articles report:

- Special schools lack adequate staff, with extant staff having insufficient knowledge to teach children with disabilities (in ten of the articles).

- Special schools lack resources, including equipment, assistive devices and infrastructure (in five of the articles).

- Education in the mainstream does not meet the learning needs of children with disabilities (in four of the articles).

Third, the education department is seen as not fulfilling its mandate to ensure that children with disabilities realise their constitutional right to education (in nine of the articles) and has not adequately implemented the policy on inclusive education (in four of the articles).

A fourth issue is the differentiation between disability that requires specialised teaching skills and technology (visual or hearing) and disability that requires care and relief of the burden on the family (intellectual and multiple). This is evident in varying degrees across the articles, with two having a clear focus on the specific technology and learning needs of blind learners. The message here is clear: children with disabilities constitute a problem on the basis of their impairment (Wood 2012). A simple binary between disabled and non-disabled is assumed (Goodley 2017) and disability corresponds with difficult-to-meet learning needs that are best addressed in segregated settings (Erevelles 2000)

\subsection{Disability as individual tragedy}

In delivering this content, the articles mostly reinforce the individual tragedy stereotype ('ag shame', in the South African idiom) about disability. In many cases this pity is directed toward the burden that the family faces rather than the needs of the child. This is achieved through telling individual stories, the use of numbers and lists, and headlines. These content 
and linguistic choices build patterns which convey three key messages about children and young people with disabilities and their schooling. These messages are that children and young people with disabilities are deficient, pitiable and helpless; that ensuring the right to education for children with disabilities is an overwhelming problem; and that education for children with disabilities requires specialist provision in segregated settings. Before discussing these messages, we identify the content and linguistic choices made in the articles and their effect.

\subsubsection{Content and linguistic choices}

\subsubsection{Telling an individual story}

The details and circumstances of individuals' lives are told, ostensibly to make the story more personal, and to build readers' empathy. Typically, the stories name caregivers, the child with a disability, and details about their lives. In John (Mail and Guardian 2014), we read, Boniswa lives with his 30-year-old unemployed mother, Nonhlanhla Mthembu, and his retired grandmother in a house made of stones, mud and wooden poles... There are no books, toys or a TV, so Boniswa follows his mother around all day as she cooks and cleans.

Later in the same article, the journalist reports sitting in another home ... on the family's brown suede lounge suite, but seven-year-old Neliswe can't keep still. She has epileptic seizures about twice a year, despite being on medication. Her mother, Esther, says she is intellectually disabled because of the seizures.

These accounts of people's lives offer details that are peripheral to the story, like the nature and colour of their clothes and their furniture. The effect is to position the reader as voyeur. The voyeur's gaze remains contiguous with disability. From the freak shows of the past, to television documentaries about different bodies, to fiction that sensationalises different 
behaviours and ways of being, disability is put on parade for audiences (Walton 2016). In the articles we examined, this voyeurism is compounded with 'poverty porn' - a genre (usually on television) that exhibits the hardships of people with limited incomes (Jensen 2014). The audience, in our case the reader, invades the privacy of the home and gazes at the subjects of the story. The gaze is unidirectional and consuming, and the distance created by the medium suspends the 'don't stare' rule of etiquette that would operate in personal encounters.

The quoted words of parents or caregivers adds authenticity, and further personalises the stories. The parent of Bongani Bongolam in Chipangura (IOL 2015) is reported as saying, All the teachers at the crèches that I have taken him to always tell me not to bring him back saying he's disruptive, hyperactive, doesn't not listen, doesn't like to be helped or needs individual attention that they cannot afford as they have many other children to take care of.

The tale of schools rejecting children is repeated by parent Esther in John (Mail \& Guardian 2014) who is quoted as saying,

The ordinary school she is at said she isn't allowed back next year because teachers complain that she is aggressive with the other children ... She breaks all the things, windows ... (Ellipsis dots in the original).

This stylistic device gives voice to parents, but the quoted words will have been selected by the article writer. The critical reader must question why these quotes were selected, as it seems like they constitute graphic and forceful accounts of the deficits of the children. The intended effect is sympathy for parents whose children are not in school, but at the same time, builds the idea that children with disabilities are disruptive, and not really suited for ordinary schooling. They are out of control, "unruly bodies" that will not be disciplined (Erevelles 2000, 33) 
The emphasis in these individual stories is on what children with disabilities cannot do. The individual story in John (Mail \& Guardian 2013) is informed by the sister of a learner in a special school. The sister, Mbiza, is reported as saying that, "her deaf brother's language skills are "very bad". He can't construct sentences. When he sends me text messages I can't figure out what he's saying." Another article by the same journalist, (John, Mail \& Guardian 2014) describes Boniswa, who is out of school, saying that, "He can't read or write, and when I ask him to draw himself in the sand, he can't do that either." Bongani, described by Chipangura (IOL 2015), is "still not potty-trained, can neither feed himself nor speak". Deficit is compounded with deviance, and children with disabilities are described as disruptive and even dangerous, almost subhuman. The special school described by John (Mail \& Guardian 2013) is “... quiet, except for the occasional incoherent shout from a deaf pupil”. The governing body chairperson of that school reports that “... a pupil allegedly raped another pupil" adding that "It would not be the first time". This lack of sexual control reflects the stereotype of disabled people as sexually abnormal (Barnes 1992) and is echoed in the notion of people with disabilities being either promiscuous or asexual (McKenzie and Swartz 2011).

\subsubsection{Numbers and lists}

Charles (IOL 2017) and ANA reporter (IOL 2017) count the exact numbers of children who are on waiting lists for special schools, and reports these in terms of each province. This suggests accurate reporting and record keeping, and in the articles, it is designed to convey the scale and extent of the problem of inadequate schooling provision. Charles (IOL 2017) notes that the numbers provided by the Department of Education (in the region of 11000 
children) may be incorrect, as other sources give the number at 300000 or beyond. Macupe (Sowetan Live 2015) offers a litany of the woes of children in a specific special school:

The learners here have various disabilities, including cerebral palsy, spina bifida, muscular dystrophy, spinal muscular atrophy and in addition many children are epileptic. There are many children on medication including ARVs, epileptic medication and anti-psychotic drugs among others. The conditions of many of the children require special nursing care like care of pressure sores, bladder and bowel programmes for incontinent kids, monitoring the frequency of the epileptic fits and the routine treatment of the many minor ailments like scabies, flu, impetigo, ear infections and diarrhoea.

This list constitutes over-lexicalisation, which “... is the existence of an excess of quasisynonymous terms for entities and ideas that are a particular preoccupation or problem in the culture's discourse" (Fowler 1991, 85). Over-lexicalisation is typically used in news articles characterise oppressed populations, and it gives a sense of excess or overabundance (Lean 2008). The list combines the medical terminology of diagnoses, with the colloquialisms of "kids" and "fits", conveying disability in medical terms, and revealing an underlying disrespect. The list of 'minor ailments' is gratuitous, including 'scabies' and 'diarrhoea' which have particularly negative connotations.

\subsubsection{Headlines}

Headlines in online news articles must attract readers and "lure" (Kuiken et al. 2017, 1300) them in. For print publications, the main purpose of the headline is to offer some summary for the benefit of the reader browsing through a whole newspaper. The digital headline, by contrast, is 'clickbait' which is characterised by "Simplification, spectacularization, negativity, and provoking content" (1303). The lexical choices made in devising the 
headlines for the analysed articles function as clickbait and reinforce the individual tragedy stereotype. Two of the articles refer to "special needs" children, three refer to "special (needs) schools" and five refer to children with disabilities, or disabled children (both terms would be acceptable in South Africa). Most headlines contain emotive words with negative connotations (e.g. "struggle" (John, Mail \& Guardian 2015), "hostel of horror" (John, Mail \& Guardian 2013), "shocking state" (Fish Hodgson and Khumalo, Mail \& Guardian 2015) and "failure" (Botha, Herald Live 2017)) and signal lack or absence in some way (e.g. "no place" (John, Mail \& Guardian 2014), “out of reach" (Ngwenya, IOL 2015) and "lack support staff" (Dhanook, IOL 2017)). Few verbs are used in the headlines, and those that do, use few material processes. This means there is little action suggested in the headlines, a state of being is presented. This is reinforced by the present tense, which gives a sense of truth and certainty (Janks 2010). The notion of disability as a static, intrinsic, organic state is presented rather than a dynamic state in interaction within the environment (Biklen 2000)

\subsubsection{The message}

The articles position people with disabilities in particular ways and position the reader in relation to the subject. Taking headlines and written text into account, together the articles present the following messages.

\subsubsection{Children and young people with disabilities are deficient, pitiable and helpless}

The articles emphasise disability as deficit by focusing on what it is that children and young people with disabilities cannot do, and how their intellectual, physical and sensory skills are deficient in comparison to those of able children and young people. The articles reinforce ableist conceptions of disability as a devalued and negative state that does not conform to the compulsory norm of the perfect body that is fully human and deserving. 
A clear binary is created between those who are disabled or have special needs, and other children, which buttresses the assumption of the need for segregated educational provision. Critical disability studies leads us to ask about the ways in which these supposed binaries actually co-construct each other and far from being entirely separate entities, disability comes to define ability and vice versa (Campbell, 2009). The existence of the children who do not belong in the regular school defines the regular school.

The individual tragedy trope in the articles cast children with disabilities and their families as the passive victims of an uncaring education system and broader society. This is not to suggest that the system is not brutal and dehumanising, but that the various the people reported in the individual stories are seldom shown to be actors in their lives. The children and young people with disabilities do not speak for themselves in the articles, they are spoken about, or spoken for. The world is thus cast into two types of people: those who are weak, powerless, and need help (the children with disabilities and their families) and those who (potentially) help them. As explained above, the vantage point of the powerful (reader/reporter) allows an invasive, even voyeuristic gaze on the details of people's lives, including their impaired bodies, their impoverished living conditions and their family arrangements. This, in turn, reinforces alterity as these poor children and people with disabilities are cast as very different from the presumed reader (able, schooled, literate and with internet access).

\subsubsection{Ensuring the right to education for children with disabilities is an overwhelming} problem

The emphasis on the number of children with disabilities out of schools, the accounts of the extent and severity of impairments among children and young people, and the emphasis on 
barriers to access (transport, cost etc.), positions the education of children and young people with disabilities as an insurmountable problem. While the reader may read these details with sympathy for the people affected, there is a sense in which the problem of a lack of educational access is so complex, it is beyond resolution. In 1993, Coleridge expressed concern about the effects of overestimating the incidence of disability. He commented, ...the size of the problem is likely to appear so daunting for hard-pressed governments and those planning services with slim resources that they may be reluctant even to embark on concerted action(108).

We are not suggesting here that the news reports overestimate the extent of children and young people with disabilities who are out of school - in fact, they are probably underestimated. But we do maintain that the articles present the issue as such a 'daunting' problem that preserving the status quo seems a more expedient and efficient option.

Furthermore, the wider context of poor educational outcomes of regular schools in South Africa ought to be considered. Spaull $(2015,34)$ notes that: "The poor quality of education that learners receive helps drive an intergenerational cycle of poverty where children inherit the social standing of their parents or caregivers, irrespective of their own abilities or effort." This context is not invoked in the discussion of education of children with disabilities as their impairment overshadows all other barriers that they might face and becomes the problem to address. However, children with disabilities face the same socio-economic barriers that children without disabilities face and would equally benefit from systemic interventions designed to address these barriers.

6.2.2.3 Education for children with disabilities requires specialist provision in segregated settings 
Most of the articles do not question the assumption of the need for more special school provision for children and young people with disabilities. While mention is made of inclusive education, it is generally described as having failed. The solution to the compounded problem of children with disabilities not in school, the lack of places in special schools, and inadequate resourcing of special schools is not a call for the effective implementation of inclusive schooling, but for the expansion and strengthening of segregated special schooling. This is in spite of the Salamanca Statement's assertion that developing and resourcing inclusive mainstream schools is a more cost effective than building more special schools in a country's endeavour to address educational provision for children with disabilities (Unesco 1994). Walton (2016) writes elsewhere about how newspaper articles in South Africa position inclusive education as a challenge, with overwhelming barriers to its implementation. These fifteen articles contribute to this negative public discourse. John (Mail \& Guardian 2013) specifically includes a subheading "Integration policy falls flat" and indicates its distance from inclusive education by putting the word "inclusive" into scare quotes in the text. Taken together, the articles present children with disabilities as very different, very deficient, and very deviant and so confirm in readers' minds that separate special schooling is required. These articles shore up the stereotype of "The Disabled Person as Incapable of Participating Fully in Community Life" (Barnes 1992, np). This stereotype is built around absence from valued community activities, in this case schooling, and fuels the idea that separate provision is the only option.

\subsection{Government failure}

The analysed articles rehearse public frustration with inadequate government service delivery and contribute to the "extensive and voluminous" media coverage of "maladministration or mismanagement of public resources" (Malila 2017, 2). They follow a "formulaic pattern" of 
reporting an event or situation (in this case, children or young people with disabilities or special schools), and then asking a government official to comment. Seven of the articles refer to actions that the government, through the education department, are taking to address schooling for children with disabilities. This includes information on mainstream schools that enrol children with disabilities (Macupe, Sowetan Live 2015), gathering data on numbers of children with disabilities who are out of school (John, Mail \& Guardian 2015; Charles, IOL 2017), and responses to situations raised in the articles (John, Mail \& Guardian 2017; Botha, Herald Live 2017). Some of the articles mention legal and Non-Government Organisations which have become involved in the quest to secure children's right to education (John, Mail \& Guardian 2013, 2014, 2015; Gedye, Mail \& Guardian 2016; Phillips, IOL 2017) and three articles (Charles, IOL 2017; ANA reporter, IOL 2017; Chipangura, IOL 2013) note that the official opposition party in parliament has taken up the issue.

We see at least two problems with the pattern of reporting on government failure exemplified by these articles. The first is that instances of maladministration are reported like any other newsworthy event, and so inability to deliver on policy becomes normalised (Malila 2017). The events are individualised, and not linked with wider structural failure. In this case the link to the general education systems is not made and children with disabilities are seen as an anomaly, rather than a sizeable proportion of children entitled to compulsory education. The problem with this, says Malila (2018, np), is “There's little or no investigation of how this maladministration was allowed to occur and how it will be prevented from happening again." The result, she maintains, is a citizenry without the contextual knowledge needed to hold the government to account. 
The second problem is that the fifteen analysed articles approach the issue of the lack of access to education for children and young people with disabilities as if it has no historical context, implying that the post-apartheid government is solely responsible for the deplorable state of affairs described. In so doing, we argue that these articles contribute to the manufacture of amnesia, or what Steyn (2012) calls the 'ignorance contract'. Apartheid's legacy cannot be underestimated in any accounts of the present failures of the post-apartheid government. This is no less evident in the provision of education for children and young people with disabilities. From education-specific legacies of special schools being set up in whites-only areas and specialist training only being available for white teachers, to the broader political challenges of "... balancing elements of social justice, the desire to be internationally competitive and the need for fiscal discipline" (Spreen and Vally 2010, 140141), the post-apartheid government is faced with a herculean task in securing both educational access and redress. By only describing the failures of the current regime to address the right to education for children with disabilities, the systemic injustices of apartheid are erased and blame is placed squarely on the current political dispensation. Readers can experience the intended shock and pity as they read the articles, without any inconvenient reminder of how apartheid engendered and shaped the current 'challenges'. It is here that we need to take up the challenge to critical disability studies made by Grech (2017) and Erevelles (2000) to move beyond the realm of the discursive into the material and structural conditions that maintain inequality across a range of marginalised identities.

\section{A resistant reading}

In our resistant reading we reject the binaries between disabled/non-disabled, regular/special school, normal/abnormal and so on. The categories depend on each other for their existence and in the education context one must begin to ask what purpose special schools serve. The 
articles show an ambivalent telling of this with special schools often being seen as the only option but also not being represented as good places to go to. If we move away from the binaries and begin to understand how these supposed opposites actually co-construct and define each other (Campbell 2009), we might gain deeper insight into the problem of poor educational outcomes in South Africa and explore the possibilities of quality education for all children. The taken for granted adoption by the media of an ableist perspective that devalues disability must also be challenged (Wood 2012). Nuanced stories that move away from the under or overachieving tropes of disability make room for seeing potential as well as needs. Granting parents and their children with disabilities agency in addressing their challenges can build a different perception of families as resourceful and resilient. Foundational to this effort is moving away from an individual, medical, tragedy model that defines the person by their disability in a negative, oppressive way. Importantly, this is not about the denial of difference but the valuing and accommodation for difference in meaningful ways that enable access and participation in education (McKenzie et al, 2018).

\section{Conclusion}

Representation matters. Because of this, many scholars have researched the ways in which disability is represented in the media. Our contribution is to use the tools of critical literacy and concepts from critical disability studies to expose ways in which the news media in South Africa represent the education of children with disabilities. This is important, because the news media both shapes and reflects public opinion, and Unesco $(2018,7)$ reminds us that 'Communities with discriminatory beliefs and attitudes can prevent learners from accessing education opportunities.' It seems that not much has changed since 2006 when McDougall reported on the representation of people with disabilities in the South African media. The same stereotypes can still be found in online news articles with individual tragedy (or 'ag 
shame') prevailing as the dominant trope in reports about education. In this chapter, we have revealed the language and content choices in news articles that work together to position children and young adults with disabilities in this way, and have shown how readers are positioned in relation to these subjects. Instead of promoting affirming disability awareness and advocacy, and locating the experiences of children and young people with disabilities within a context of systemic discrimination and oppression, the articles evoke shock and pity, but ultimately achieve little more than an exercise in public handwringing. We would like to see news outlets challenged to explore the issue of the education of children with disabilities in ways that move away from understanding special and ordinary schools as binary opposites. Instead, they should consider how and in what ways children with or without disabilities access a better quality education through addressing all barriers to learning. There also needs to be a concerted attempt to portray disability in a much more complex and nuanced way which allows individual agency without resorting to stereotypes, and to challenge ableist views of disability as deficit. Finally, we argue that these analyses cannot be ahistorical, and the roots of deprivation need to be understood from the country's apartheid past. 


\section{References}

Biklen, D. (2000). "Constructing inclusion: Lessons from critical disability narratives". International Journal of Inclusive Education, 4, 337-353.

Brookfield, Stephen. 2005. The power of crtical theory for adult learning and teaching. Maidenhead: Open University Press.

Coleridge, Peter. 1993. Disability, Liberation, and Development. Oxford, Oxfam. Campbell, Fiona. 2009. Contours of ableism: The production of disability and abledness. Basingstoke: Palgrave.

Department of Education (DoE). 2001. White Paper Six: Special Needs Education. Building an Inclusive Education and Training System. Pretoria: Department of Education.

Department of Basic Education (DBE) (2011). Guidelines for responding to learner diversity in the classroom through curriculum and assessment policy statements. Pretoria: Department of Basic Education.

Department of Basic Education (DBE) (2014). National Strategy on Screening, Identification, Assessment and Support. Pretoria: Department of Basic Education.

Donohue, Dana and Juan Bornman. 2014. "The challenges of realising inclusive education in South Africa." South African Journal of Education, 34(2):1-14.

Ellis, K. (2008). "Beyond the Aww Factor: Human interest Profiles of Paralympians and the media navigation of physical difference and social stigma". Asia Pacific Media Educator, (19): 23.

Fairclough, Norman. 2001. Language and power. 2nd ed. Harlow: Pearson.

Fleisch, Brahm, Jennifer Shindler, and Helen Perry. 2012. "Who is out of school? Evidence from the Statistics South Africa Community Survey." International 
Journal of Educational Development 32(4):529-536. doi:

https://doi.org/10.1016/j.ijedudev.2010.05.002.

Flynn, Susan. 2017. "Engaging with materialism and material reality: critical disability studies and economic recession." Disability \& Society 32(2):143-159. doi: 10.1080/09687599.2017.1284650.

Fowler, Roger. 2001. Language in the News: Discourse and Ideology in the Press. London: Routledge.

Freebody, Peter, and Allan Luke. 1990. "Literacies programs: Debates and demands in cultural context." Prospect: An Australian Journal of TESOL 5(3): 716.Goodley, Dan. 2017. Disability studies; An interdisciplinary introduction 2nd ed. London: Sage.

Goodley, Dan. 2013. "Dis/entangling critical disability studies." Disability \& Society 28(5):631-644. doi:10.1080/09687599.2012.717884.

Human Rights Watch. (2015). “Complicit in exclusion” South Africa's Failure to Guarantee an Inclusive Education for Children with Disabilities. Accessed 1 May 2018 from $\quad$ https://www.hrw.org/report/2015/08/18/complicitexclusion/south-africas-failure-guarantee-inclusive-education-children

Janks, Hilary. 2012. "The importance of critical literacy." English Teaching: Practice and Critique 11(1):150-163.

Janks, Hilary. 2010. Literacy and power. New York: Routledge.

Janks, Hilary. 2005. "Language and the design of texts." English Teaching: Practice and Critique 4(3): 97-100.

Kliewer, Christopher, Douglas Biklen, and Christi Kasa-Hendrickson. 2006. Who may be literate? Disability and resistance to the cultural denial of competence American Educational Research Journal, 43(2): 163-192. 
Kuiken, Jeffrey, Anne Schuth, Martijn Spitters, and Maarten Marx. 2017. "Effective Headlines of Newspaper Articles in a Digital Environment." Digital Journalism 5 (10):1300-1314. doi: 10.1080/21670811.2017.1279978.

Lean, Mei Li. 2008. “New Kids on the Block': The Discursive Construction of two New Premiers by the Mass Media." Critical Approaches to Discourse Analysis across Disciplines 2(1):59 - 75, Accessed 26 April 2018 from http://cadaad.org/ejournal.

Luke, Allan. 2012. "Critical Literacy: Foundational Notes." Theory Into Practice 51(1):4-11. doi: 10.1080/00405841.2012.636324.

Jensen, T., 2013. “A summer of television poverty porn”. The Sociological Imagination 9. Accessed 16 February 2019 from http://sociologicalimagination.org/archives/14013

Malila, Vanessa. 2017. Beyond watchdog journalism: Media and Social Accountability. Grahamstown: Public Service Accountability Monitor. Accessed 9 May 2018 from: http://psam.org.za/wp-content/uploads/2016/11/Role-of-media-in-Social$\underline{\text { Accountability-Final.pdf }}$

Malila, Vanessa. 2018. "South Africa's print media is failing to empower citizens on corruption." The Conversation, 2 May. Accessed 9 May 2018 from https://theconversation.com/south-africas-print-media-is-failing-to-empowercitizens-on-corruption-95315

McDougall, Kathleen. 2006. "Ag shame and Superheroes: Stereotypes and the Signification of Disability." In Disability and Society, edited by Brian Watermeyer, Leslie Swartz, Theresa Lorenzo, Marguerite Schneider and Mark Priestley, 387 - 400. Pretoria: HSRC Press. 
McMillan, James, and Sally Schumacher. 2010. Research in Education: evidence based enquiry. 7th ed. New Jersey: Pearson.

Meekosha, Helen, and Russell Shuttleworth. 2009. "What's so 'critical' about critical disability studies?" Australian Journal of Human Rights 15(1):47-75. doi: 10.1080/1323238X.2009.11910861.

Nkabinde, Zandile. 1993. "The role of special education in a changing South Africa". The Journal of Special Education 27(1): 107 - 114.

Oliver, Michael. 1996. "Defining impairment and disability: Issues at stake." In Exploring the Divide, edited by Colin Barnes and Geof Mercer, 29-54. Leeds: The Disability Press.

Phillips, Sarah D. 2012. "Representations of disability in print news media in postsocialist Ukraine." Disability \& Society 27(4):487-502. doi: 10.1080/09687599.2012.662826.

Republic of South Africa (RSA). 1948. Act 9. Government Gazette 3960. Government Printers: Pretoria.

Serafini, Frank. 2011. "Expanding Perspectives for Comprehending Visual Images in Multimodal Texts.” Journal of Adolescent \& Adult Literacy 54(5):342-350. doi:10.1598/JAAL.54.5.4

Skuy, M. and Partington, H. 1990. "Special education in South Africa." International Journal of Disability 37(2): 149-157.

Spreen, Carol Anne, and Salim Vally. 2010. "Prospects and pitfalls: A review of postapartheid education policy research and analysis in South Africa." Comparative Education 46(4):429-448. doi: 10.1080/03050068.2010.519478. 
Steyn, Melissa. 2012. "The ignorance contract: recollections of apartheid childhoods and the construction of epistemologies of ignorance." Identities 19(1):8-25. doi: 10.1080/1070289X.2012.672840.

Eamon Tewell. "Toward the Resistant Reading of Information: Google, Resistant Spectatorship, and Critical Information Literacy." portal: Libraries and the Academy, 16(2): 289-310. Accessed 16 February 2019 from https://muse.jhu.edu/

United Nations. 2006. Convention on the Rights of Persons with Disabilities and Optional Protocol. Accessed 1 May 2018 from http://www.un.org/disabilities/documents/convention/convoptprot-e.pdf

Unesco. 1994. The Salamanca Statement and framework for action. Paris: Unesco

Unesco. 2018. Concept note for the 2020 Global education monitoring report on inclusion. Paris: Unesco. Accessed 16 February 2019 from https://unesdoc.unesco.org/ark:/48223/pf0000265329

Walton, E. 2016. The language of inclusive education. Milton Park: Routledge. Walton, Elizabeth. 2011. "Getting Inclusion Right in South Africa." Intervention in School and Clinic 46(4):240-245. doi: 10.1177/1053451210389033.

Wilkinson, Penny, and Peter McGill. 2009. "Representation of People with Intellectual Disabilities in a British Newspaper in 1983 and 2001." Journal of Applied Research in Intellectual Disabilities 22(1):65-76. doi: doi:10.1111/j.14683148.2008.00453.x.

Wood, L. 2012. A Critical analysis: Overview of the media. Disability Planet http://www.disabilityplanet.co.uk/critical-analysis.html Retrieved 19 December 2018 
Zhang, Lingling, and Beth Haller. 2013. "Consuming Image: How Mass Media Impact the Identity of People with Disabilities." Communication Quarterly 61(3):319334. doi: 10.1080/01463373.2013.776988. 